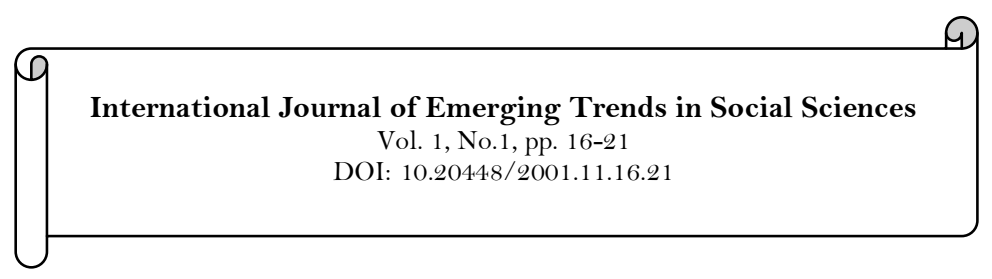

\title{
An Analysis of Women Farmers in Rice Production in Donga Local Government Area of Taraba State
}

\author{
Abuh, Paul Ojochenemi ${ }^{1}$ \\ Romanus Gabriel ${ }^{2}$ \\ Joshua Ogwuche ${ }^{3}$ \\ ${ }_{1,2}^{1,2}$ Department of Geography, Kwararafa University, Wukari, Taraba State, Nigeria \\ ${ }^{s}$ Department of Public Administration, Kwararafa University, Wukari,Taraba State, Nigeria.
}

\begin{tabular}{|c|c|}
\hline Abstract & \\
\hline $\begin{array}{l}\text { The study focuses on Analysis of Women Farmers in Rice } \\
\text { Production in Donga Local Government Area of Taraba State. A } \\
\text { total of } 120 \text { Questionnaire were collected and subjected to descriptive } \\
\text { statistical analysis. The study used purposeful sampling technique to } \\
\text { choose two (2) wards out of the ten (10) political wards in Donga } \\
\text { Local Government Area of Taraba State. The two (2) wards were } \\
\text { Akate and Asibiti wards. Also, random sampling was used to } \\
\text { distribute the questionnaires among the respondents in the two (2) } \\
\text { wards selected. In each of the wards, twelve (12) households were } \\
\text { randomly selected and five (5) questionnaires were distributed to } \\
\text { each of the household. The Chi-Square }\left(\mathrm{X}^{2}\right) \text { test was used to ascertain } \\
\text { the relationship between the factors affecting rice production by } \\
\text { women rice farmers in Donga L.G.A of Taraba State. The study } \\
\text { reveals that } 41.7 \text { percent of respondents purchase farmland for the } \\
\text { cultivation of rice. And } 40 \text { percent obtain credit facilities from } \\
\text { cooperative societies. Also, } 42.5 \text { percent of the respondents consider } \\
\text { inadequate finance as the major factor affecting rice production by } \\
\text { women farmers in Donga L.G.A of Taraba State. All stakeholders } \\
\text { must give all necessary assistance to women farmers involve in rice } \\
\text { production. }\end{array}$ & $\begin{array}{l}\text { Keywords: } \\
\text { Rice, farmers } \\
\text { Food security } \\
\text { Women participation } \\
\text { Credit facility. } \\
\text { Licensed: } \\
\text { This work is licensed under a } \\
\text { Creative Commons Attribution } \\
\text { 4.0 License. } \\
\text { Publisher: } \\
\text { Scientific Publishing Institute }\end{array}$ \\
\hline
\end{tabular}

\section{Introduction}

In most developing countries; women's role in terms of food security is recognized. This is because they make up a large number of the agricultural workforce. As such their role in agricultural production cannot be overemphasized. In Africa, it is estimated that women represent 30-80 percent of the agricultural labour force depending on the area. In most part of this region; women have been traditionally responsible for food crops and men for cash crop production (FAO, 1990).

One of the areas of food security that women contribute is the cultivation of rice. According to Ijere (1992) women farmers have been pillars of rice production among rice communities in Nigeria, producing over 90 percent of total rice output

Indeed, their roles in rice production have been noticed over the years. These roles include bush clearing, bush burning, packing, planting, weeding, harvesting, application of fertilizers and post-harvest activities in rice production.

In nearly all rice growing area men traditionally perform such activities as levelling the field. However, sowing, transplanting and weeding are usually women's work. Also, harvesting, threshing and transporting of grain from fields to home are done mostly by women (FAO, 1990).

It is important to note that women's participation in rice production have been hampered by access to land credit, agricultural inputs, education, extension services and the use of appropriate technology.

It has been observed that Donga Local Government Area of Taraba State is purely a rice community with majority of the population relying on rice production and women are mainly involve in its cultivation.

Therefore, the research seeks to analyze women farmers in rice production in Donga Local Government Area of Taraba State. 


\section{Study Area}

\subsection{Population, Location, Position and Size}

Donga Local Government Area has a total land area of about 3.121 square kilometre $\left(\mathrm{km}^{2}\right)$ and population of about 133,105 (NBS,2012).

Donga local government is one of the sixteen Local Government Areas of Taraba State. The inhabitants are predominantly farmers. Others are civil servants, hunters and traders.

Geographically, Donga Local Government Area lies within latitude 7' 43"N of the equator and longitude $10^{\circ} \mathrm{E}$ of the meridian with the land area of approximately 58 square kilometres. It shares a common international boundary with Cameroon Republic and it is locally bordered to the northwest by Bali Local Government Area, Southeast by Takum Local Government Area, from the Northeast by Kurmi Local Government Area and to the Southwest by Wukari Local Government Area. Donga has ten (10) political wards namely: Fada, GyataAure, Kumbo, Mararaba, Kadarko, Akate, Suntai, Asibiti, Gayama and Nyita Ward.

The main ethnic groups' are Chamba, Ichen and Kpazon. Other ethnic groups include Hausa, Tiv, Igbo and Yoruba etc.

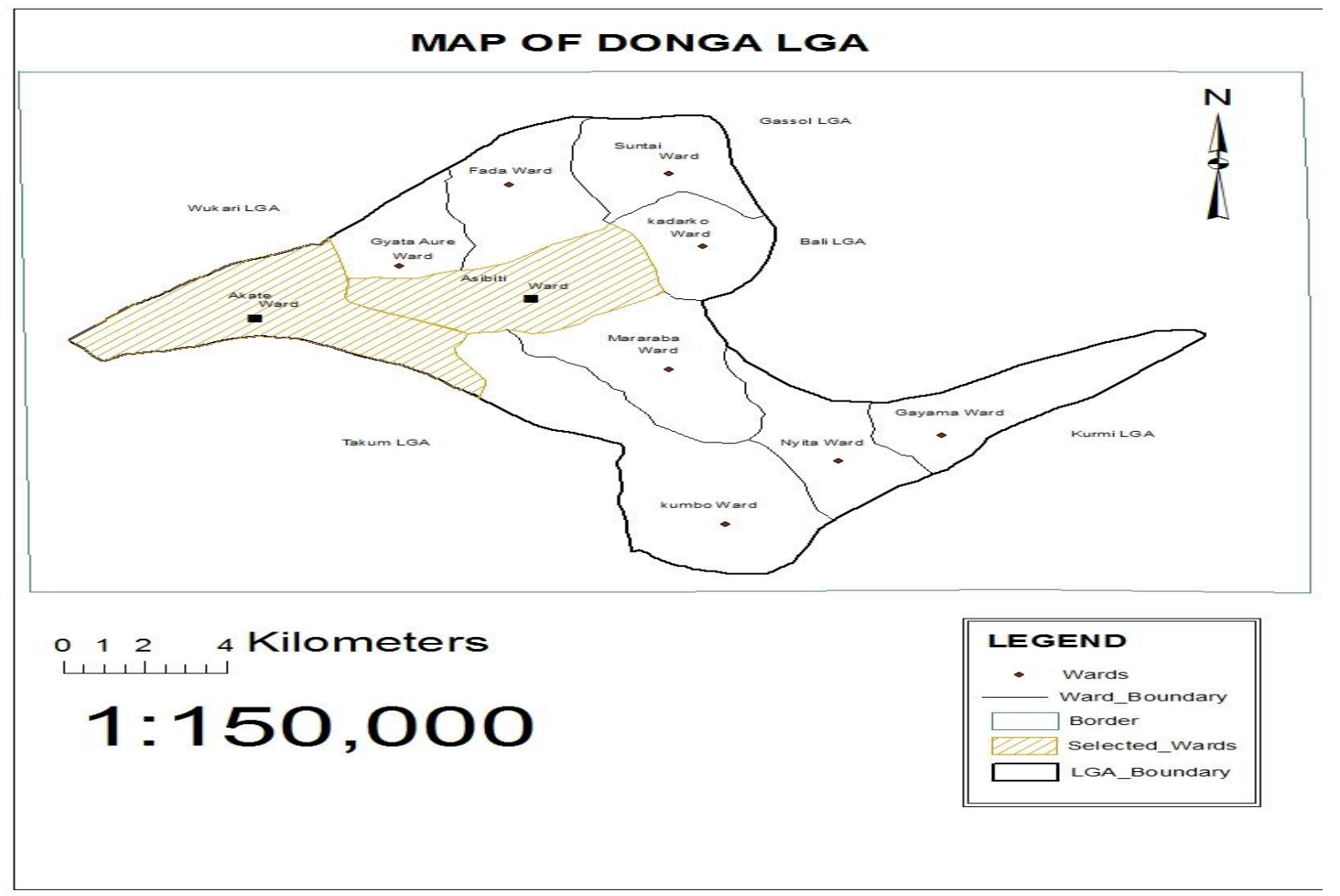

Figure-1. Map of Donga LGA showing the selected wards. Source: GIS and Remote Sensing Lab, Kwararafa University, Wukari. 


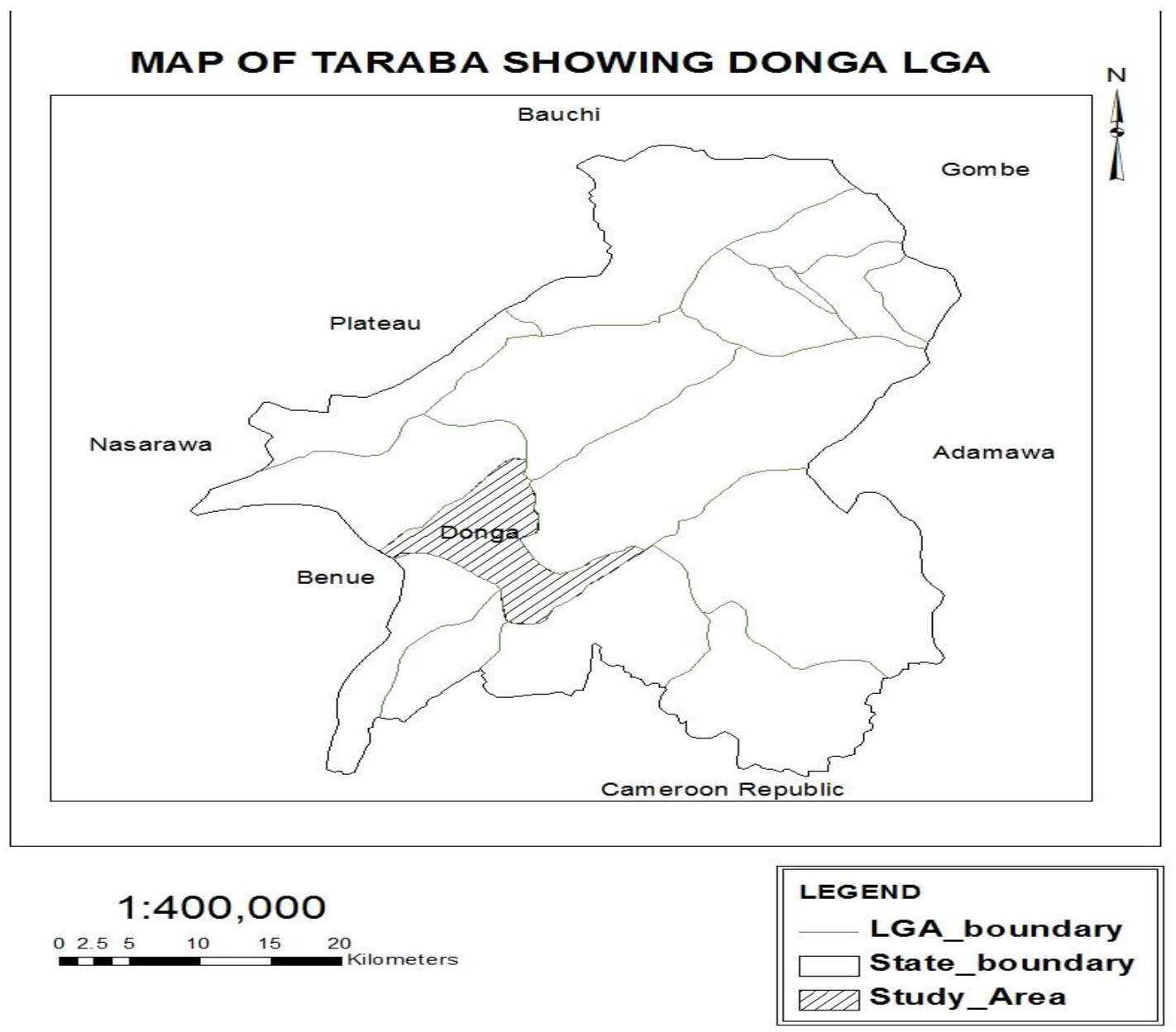

Figure-2. Map of Taraba state showing the study area.

Source: GIS and Remote Sensing Lab, Kwararafa University, Wukari.

\section{Methodology}

The study used purposeful sampling technique to choose two (2) wards out of the ten (10) political wards in Donga Local Government Area of Taraba State. The two (2) wards were Akate and Asibiti wards. This is because the wards are the major areas of rice production. Also, random sampling was used to distribute the questionnaires among the respondents in the two (2) wards selected. In each of the wards, twelve (12) households were randomly selected and five (5) questionnaires were distributed to each of the household. Therefore, a total of one hundred and twenty (120) questionnaires were distributed.

\subsection{Hypothesis}

HO: There is no significance relationship between factors affecting rice production by women rice farmers in Donga L.G.A of Taraba State.

HI : There is significance relationship between factors affecting rice production by women rice farmers in Donga L.G.A of Taraba State.

\section{Results and Discussions}

\subsection{Demographic and Socio Economic Characteristics}

The demographic and socio-economic characteristics of the respondent will be discussed. This involves the education, marital status and occupation. 
Table-1. Demographic and Socio Economic Characteristics of Respondents.

\begin{tabular}{l|l|l}
\hline Description & Frequency(120) & Percentage (\%) \\
\hline Education & & \\
\hline Primary Education & 20 & 16.7 \\
Secondary Education & 42 & 35 \\
Tertiary Education & 58 & 48.3 \\
\hline Marital Status & & \\
\hline Single & 36 & 30 \\
Married & 68 & 56.7 \\
Widow & 10 & 8.3 \\
Divorce/Separated & 6 & 5 \\
\hline Occupation & & \\
\hline Farming & 68 & 56.7 \\
Teaching & 13 & 10.8 \\
Business & 31 & 25.8 \\
Others & 8 & 6.7 \\
\hline Source: Field Survey, 2016. & &
\end{tabular}

Table 1 shows that 16.7 percent of the respondents acquired primary education, 35 percent of them acquired secondary education and 48.3 percent of the respondents acquired post-secondary school. The above analysis indicates that 48.3 percent which is half of the respondents had post-secondary school in Donga Local Government Area. Therefore, the women in this community are educationally okay.

Also, the table indicates that 56.7 percent are married, 30 percent single, 8.3 percent widow and 5 percent of the respondent are divorce/separated. These suggest that the women are involved in rice farming for food security.

Furthermore, 56.7 percent of the respondents are farmers, 10.8 percent of the respondents are teachers, 25.8 percent of the respondents engaged in business while 6.7 percent of the respondents engaged in other activities. From the above analysis 56.7 percent of the respondents are engaged in farming in the study area. And therefore, a reasonable percentage may be involved in rice production.

\subsection{Activities of Women Rice Farmer in Donga L.G.A of Taraba State}

The activities involve by women rice farmer was sought and analyzed.

Table-2. Distribution of Respondents by Activities involve in Rice Production.

\begin{tabular}{|c|c|c|}
\hline Description & Frequency(120) & Percentage (\%) \\
\hline \multicolumn{3}{|l|}{ Access to Farmland } \\
\hline Borrowing & 25 & 20.8 \\
\hline Purchase & 50 & 41.7 \\
\hline Inheritance & 36 & 30 \\
\hline Others & 9 & 7.5 \\
\hline \multicolumn{3}{|l|}{ Method of Cultivation } \\
\hline Tractor & 82 & 68.3 \\
\hline Hoe and Cutlass & 29 & 24.2 \\
\hline Drown Plough & 9 & 7.5 \\
\hline \multicolumn{3}{|l|}{ Method of Storage } \\
\hline Bags & 50 & 41.7 \\
\hline Drum & 25 & 20.8 \\
\hline Tins & 36 & 30 \\
\hline Wooden Chest & 9 & 7.5 \\
\hline \multicolumn{3}{|c|}{ Method of Harvesting Rice } \\
\hline Knife & 31 & 25.8 \\
\hline Sickle & 89 & 74.2 \\
\hline \multicolumn{3}{|c|}{ Source of Access to Credit Facilities } \\
\hline Local Government & 25 & 20.8 \\
\hline State Government & 4 & 3.3 \\
\hline Cooperative Society & 48 & 40 \\
\hline Banks & 9 & 7.5 \\
\hline Personal Saving & 34 & 28.3 \\
\hline \multicolumn{3}{|c|}{ Credit Facility Obtained } \\
\hline N 5,000-20,000 & 3 & 2.5 \\
\hline N 30,000-100,000 & 20 & 16.7 \\
\hline N 110,000-200,000 & 12 & 10 \\
\hline
\end{tabular}




\begin{tabular}{l|l|l}
\hline $\mathrm{N} 210,000-290,000$ & 15 & 12.5 \\
$\mathrm{~N} 300,000+$ & 70 & 58.3 \\
\hline Annual Harvest & & \\
\hline Less than 4 bags & 18 & 15 \\
$5-9$ bags & 26 & 21.7 \\
10-14 bags & 10 & 8.3 \\
$15-19$ bags & 22 & 18.3 \\
20 and above bags & 44 & 36.7 \\
\hline Source: Field Survey, 2016. &
\end{tabular}

Table 2 shows that 20.8 percent of respondents borrowed farm land for their farming activities, 41.7 percent purchased the farmland, 30 percent inherited the farmland and 7.5 percent of the respondents got their farm land by different means like, free, gift, honorary award won from a contest etc. This suggest that most of the farm land for rice cultivation are purchased

Also, 68.3 percent of the respondents used tractor as method of cultivation, 24.2 percent use Hoes and Cutlasses and 7.5 percent used Drown Plough as a method of Rice Cultivation. This is not unexpected as women Rice farmers in Donga are embracing mechanized farming.

The table indicates that 41.7 percent of the respondents with the highest responses use bags as a method of storage 20.8 percent used drum, 30 percent use Tins 7.5 percent use Wooden Chest for Storage. This suggests that Bags are readily available to be used as storage and traditional storage method is still in use

Furthermore, 25.8 percent of the respondents use Knife as harvesting tools, and 74.2 percent who are the highest respondents use Sickle for harvesting Rice Seed. This suggests that traditional method of harvesting Rice is still practiced in Donga Local Government Area of Taraba State. This is an indication that the community has not fully embrace modern method of rice farming.

More so, 20.8 percent of the respondent's source of credit facility was from Local Government, 3.3 percent from State Government, and 40 percent from Co-operative Society. While 7.5 percent from Banks and 28.3 percent source of credit facility was from their personal savings. This suggests that the formation of cooperative society is of immense contribution to women Rice farmers in Donga Local Government Area of Taraba State.

Likewise, 2.5 percent of the respondents obtained N5,000-20,000 credit facilities, 16.7 percent obtained N30,000-100,000,10 percent obtained N110,000-200,000,12.5 percent obtained N210,000-290,000 and 58.3 percent obtained credit facilities of $\$ 300,000$ and above. This is not unexpected as the women are involve in various cooperative society

Above all 21.7 percent of the respondents have 5-9 bags annually, 18.3 percent harvest 15-19 bags annually, and 36.7 percent harvest above 20 bags annually, while 8.3 percent harvest 10-14 bags and 15 percent less than 4 bags annually. This is an indication that women are involved in rice farming in Donga Local Government Area Taraba State.

\subsection{Factors affecting Women Rice Farmers in Rice Production Donga}

Several factors affect women farmers in rice production in Donga Local Government Area of Taraba State. Data on this was sought and analyzed

Table-3. Distribution of Respondents by Factors Affecting Rice Production.

\begin{tabular}{l|l|l}
\hline Factors Affecting Rice Production & Frequency (120) & Percentage (100\%) \\
\hline Inadequate Land & 13 & 10.8 \\
Inadequate Finance & 51 & 42.5 \\
High Cost of Pesticides/Fertilizer & 21 & 17.5 \\
High Cost of Labour & 28 & 23.3 \\
Scarcity/Shortage of Improved Rice Variety & 7 & 5.8 \\
\hline Source: Field Survey, 2016
\end{tabular}

Table 3 indicates that 42.5 percent of the respondents have inadequate finance as the factor affecting rice production, 23.3 percent high cost of labour, 17.5 percent high cost of pesticides/fertilizer, 10.8 percent inadequate land and 5.8 percent scarcity/shortage of improved rice variety. This is expected as government assistance is not fully felt by women rice farmers in this community.

Table-4. Chi-Square Test for Level of Significance.

\begin{tabular}{l|l|l|l|l|l}
\hline Table & Calculated $\mathbf{X}^{2}$ & Tabulated $\mathbf{X}^{2}$ & Df & SL & Remarks \\
\hline Chi-Square $\left(\mathrm{X}^{2}\right)$ Test & 45.5 & 9.49 & 4 & 0.05 & Alternate Hypothesis Accepted \\
\hline
\end{tabular}

The Chi-Square $\left(\mathrm{X}^{2}\right)$ method was utilized to determine the relationship between factors affecting rice production by women rice farmers in Donga Local Government Area of Taraba State. Table 4 indicates that the calculated value of 45.5 is greater than the tabulated value of 9.49 at 0.05 significance level with degree of 
freedom of 4. Therefore, it can be concluded that there is significance relationship between factors affecting rice production by women rice farmers in Donga Local Government Area of Taraba State.

\section{Recommendation and Conclusion}

Rice has remains one of the stable food in Nigeria. And it has been observed that women farmers in Donga Local Government Area of Taraba State are greatly involved in its cultivation and production. It is therefore necessary to make the following recommendation for increase production and participation by the women farmers in this community. The followings are some of the recommendations.

(a) Women should be allowed to have access to land through the help of the government and land reform commission to encourage their efforts and ability to participate in food crop production.

(b) Government should provide adequate finance to farmers. This will ensure their ability to purchase necessary farm inputs for increase productivity.

(c) Women are strongly encouraged to participate in rice extension trainings. Access to a wider range of information that relate to government's development policy, technical knowledge and technology and market.

(d) There is need for mass enlightenment programme on the need for active participation in agricultural production irrespective of education status.

(e) Government and non-government organizations should assist women farmers with the provision of farm inputs (such as fertilizers, improved seeds, tractors, herbicides/insecticides etc.) through their cooperative societies and make sure that the farm inputs reach those in need which will greatly improve the output of women rice farmers.

\section{References}

FAO. (1990). Rural women and food security; current situation and perspective.

Ijere, M. O. (1992). Leading issues in rural development. Enugu: ACENA Publisher. 